\title{
Research on Path Selection and Efficiency Evaluation of Accounting Informatization in China
}

\author{
LAI Lining ${ }^{1, a}$ \\ ${ }^{1}$ Sichuan electric vocational and technical college, Chengdu 610066,China \\ aLAlLining@yeah.net
}

Keywords: Accounting information; Path selection; ERP; Efficiency evaluation

\begin{abstract}
The economic benefits of enterprises is the core of enterprise accounting informatization implementation, which directly decide mode selection and implementation of enterprise accounting information and affect the long-term development of the enterprise and the prosperity of social economy. Therefore, research about the economic benefits of enterprise accounting information problem has always been one of hot issues in research of accounting. With the arrival of knowledge economy and the rapid development, informatization development and implementation of our country accountant has also made great achievements, but due to various reasons, in the development of accountant informatization in our country also exist many problems. Chinese enterprise accounting informatization path selection and economic benefit of the research are the problem to be solved.
\end{abstract}

\section{Introduction}

The economic benefits of enterprises is the core of enterprise accounting informatization implementation problems, it is directly used decided to enterprise accounting mode selection and implementation of enterprise accounting information, which affect the long-term development of the enterprise and the prosperity of social economy. Therefore, the research about the economic benefits of enterprise accounting information problem has always been one of hot issues in research of accounting. With the arrival of knowledge economy and the rapid development of China's accounting informatization development and implementation has also made great achievements, but due to various reasons such as history, system and culture, China's accounting informatization also exist many problems in development. These problems in terms of the root cause is the unreasonable for the implementation of enterprise accounting information, the reasonable scheme of accounting informatization is the important premise of enterprise development and the knowledge economy era survival and the development of the necessary conditions of accounting informatization construction and implementation of the development of Chinese enterprises and China's economic development has a positive and far-reaching significance. Therefore, the Chinese enterprise accounting informatization path selection and economic benefit of study is the problem to be solved. Based on some typical enterprises in China as an example, the Chinese enterprise accounting informatization path selection and economic benefit were studied. The theory were summarized in this review the history of accounting information, and empirical research on accounting informatization were summarized, many influence factors of accounting informatization development in China, with economic benefit as the starting point, puts forward the countermeasures of optimizing Chinese accounting informatization development.

\section{Related theory about enterprise accounting informatization}

\section{Connotation of accounting informatization}

As for accounting profession there have different understanding of the concept of accounting informatization. How to accurately grasp its connotation is the problem that the accounting profession has been discussed at present. One more representative view is as follows:

Accounting Management Informatization ISCA published in 2003 by the professor Yang 
Zhouna thought that "the accounting computerization" should be renamed as "management accounting informatization", hereinafter referred to as "accounting informatization". [1]She puts forward the information system control and auditing model, thinking the accounting management information system structure should be made up of three parts: establish and implement accounting information system (AIS) under the environment of modern information technology; a sound system of internal control of accounting information system must be established in order to ensure the AIS operation safely and effectively and provide high-quality information service for accounting management work; to review and ensure the effective implementation of internal control system, the AIS and audit of internal control system must be carried out to ultimately achieve safe, reliable, effective and efficient use of AIS (accounting information system).

Splendid history - 30 years accounting informatization publishes in China by Chinese accounting association professional committee of accounting informatization thought that accounting information is an important subset of the enterprise informatization. The core of accounting information should be defined as: modern information technology are widely used in the accounting profession and organization or enterprise to effectively develop and use the accounting information resources in accounting activities there thus make the accounting information resources become the wealth that shared by the whole society so as to promote the development of the accounting information resources industry historical process.[2] Accounting informatization strategic goal is to improve the accounting management activities and the transformation of the accounting business in accounting industry, organization or enterprise, and to promote the development of accounting career.

Actually it's not hard to see that the accounting information has carried on the reorganization for the traditional accounting pattern by using modern information technology, and based on which, the accounting information system by fusing information technology and accounting in highly; it is fully open and modern. The application of it can make the accounting business processing highly automated, information shared highly. Accounting information is not only a change in the history of information technology used in accounting, it more represents a kind of modern information technology environment and adapt to the new accounting thoughts, it changes the traditional accounting, which is the static calculation after action to the high level of real-time dynamic calculation, make accounting control and plan functions exerted fully.

\section{Development of accounting informatization}

Since the third plenary session of the eleventh in 1978, our country has gone through a journey of more than 30 years of reform and opening up. [3] Over the years, a series of accounting system reform in China makes accounting work by the simple balance of accounting development to today's cost accounting, from the planned cost of development to today's comprehensive budget management. Accounting tools are also changed from the ancient abacus into financial software, financial personnel is finally freed from the tedious bookkeeping, accounts, into the unit financial management work, work efficiency has improved greatly.

Since the late $1970 \mathrm{~s}$, our country accounting computerization experienced the attempt stage, spontaneous stage, and organized, steady stage of development in a planned way, so far has developed into a stage of management accounting software. In the process of the development, our country accounting computerization maintains a high speed development; commercialized financial software has been widely used.

Accounting informatization is developed on the basis of computerized accounting under the background of today's economic and social integration, digitization and networking conditions. It not only has the function of accounting, but also has more control and management functions. So compared with the accounting computerization, a lot of changes have taken place in terms of internal control.

\section{Analysis of input and output comprehensive evaluation index system}

In this article according to the actual analysis of the enterprise accounting information selection efficiency needs, we assume that in evaluating the economic benefits of enterprises before and after 
the implementation of enterprise accounting information is used in the evaluation of the evaluation index system by the contribution ability, profit ability, debt paying ability and product sales rate, labor productivity, value rate of increment rate, return on capital, lower costs, asset-liability ratio, capital turnover, inventory turnover, capital turnover, taxes, social accumulation rate and contribution rate of employment, etc., we will choose benefit evaluation the schematics of the accounting information of lateral quantitative analysis and enterprise accounting information select the benefit evaluation of these indicators in the quantitative analysis of longitudinal analysis on the basis of quantitative analysis, as shown in figure 1.

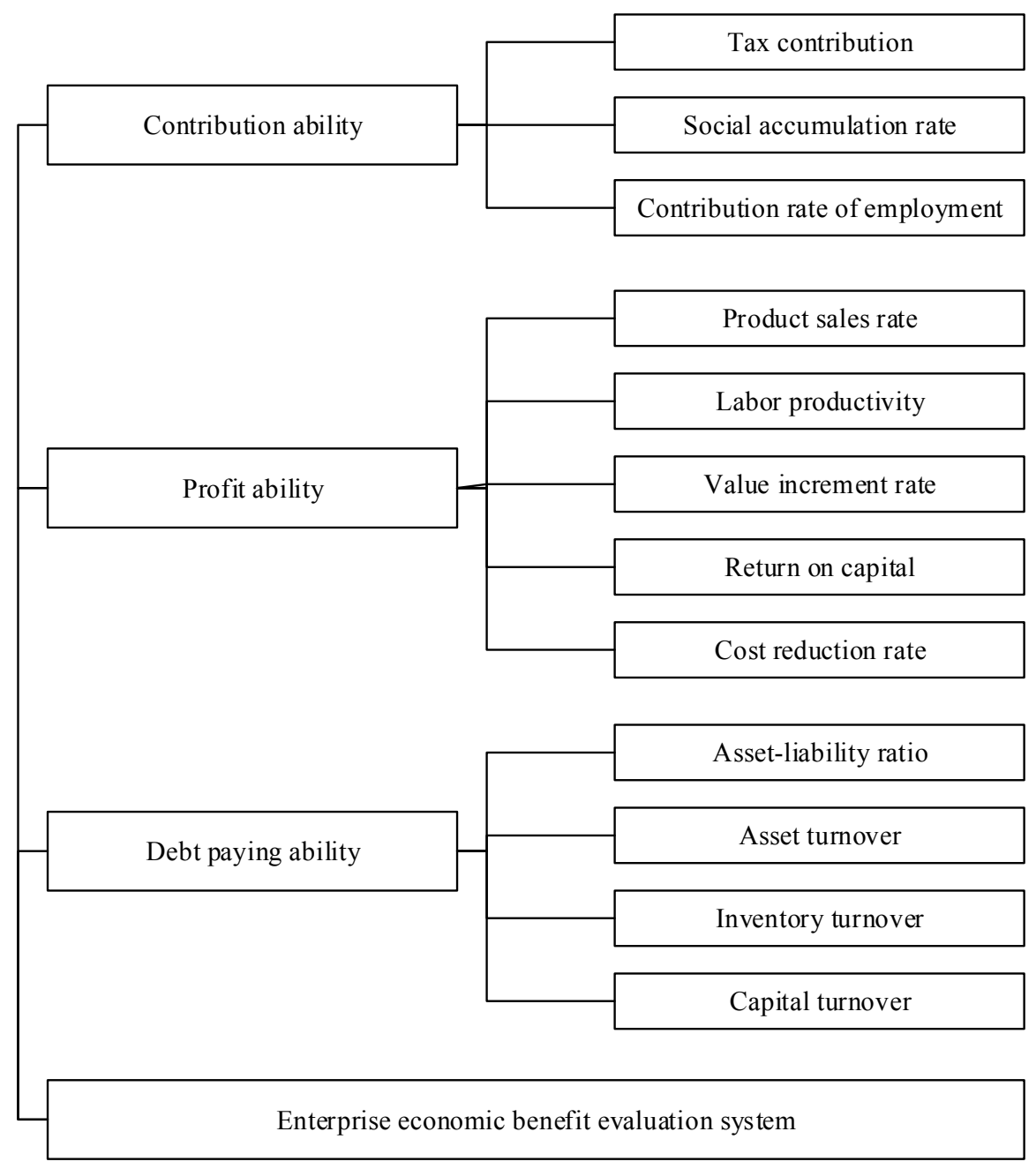

Figure 1. The economic benefit evaluation of accounting information system

\section{Input-output evaluation index system}

Comprehensive evaluation of enterprise accounting informatization is in order to adapt to enterprise development strategy, using specific indicators and the scientific method to make a value judgment the enterprise business activities in the process of accounting information management and technology. [4]Enterprise strategic target realization depends on the internal and external factors, therefore, the comprehensive evaluation index system of input and output design should not only consider most important aspects enterprise strategic goals, and the external environment has the important influence of its factors should also be considered. In the design of the comprehensive evaluation index system of enterprise accounting information the following combination should be reflected: the combination of quantitative index and qualitative index and the combination of internal and external level. 


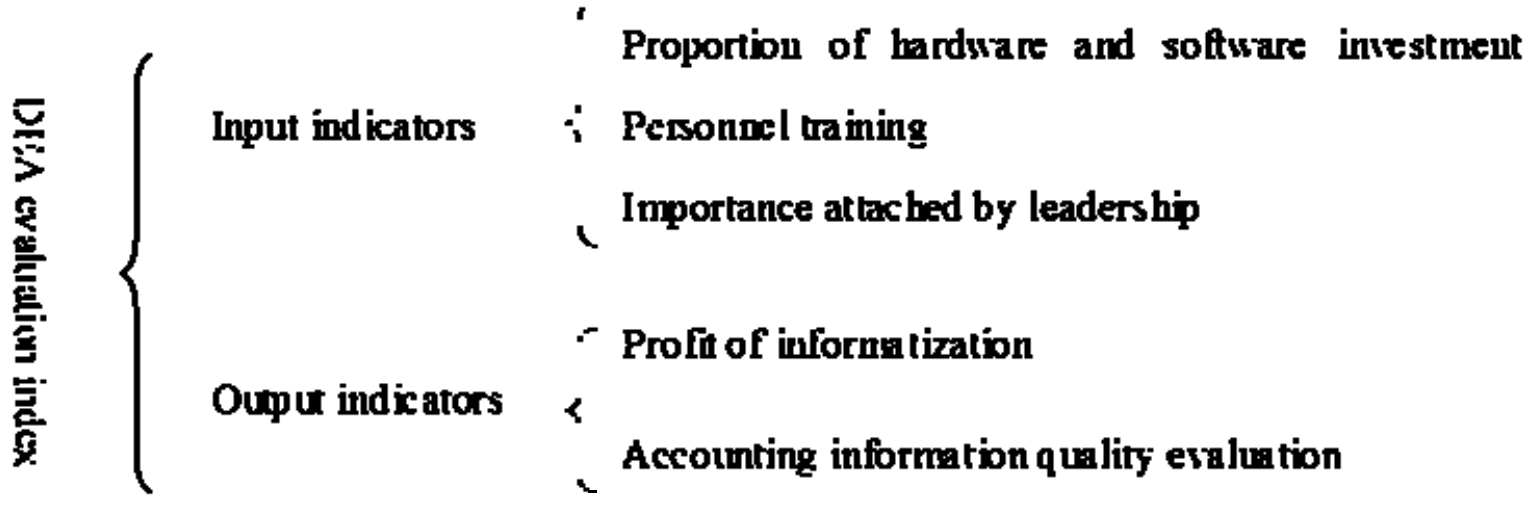

Establishes of benefit evaluation model of the enterprise accounting informatization

This section is mainly for the quantitative indicators and principle analysis of enterprise accounting informatization benefit evaluation longitudinal quantitative analysis.

1) Quantitative the enterprise economic benefit evaluation index

Assume that the existing economic indicators $n$, the enterprise by evaluated of $m$. So, we ranked data sequence as shown in below:

$$
\left.\begin{array}{c}
X_{1}=\left\{x_{1}(1), x_{1}(2), x_{1}(3), \ldots, x_{1}(k), \ldots, x_{1}(n),\right\} \\
X_{2}=\left\{x_{1}(1), x_{1}(2), x_{1}(3), \ldots, x_{1}(k), \ldots, x_{1}(n),\right\} \\
\ldots
\end{array}\right\}
$$

2) Initialization processing of evaluation data

In the process of evaluation, given the number of different data quantitative difference is bigger, not related to evaluation calculation, so need normalized data processing for each index. The normalized processing model used is:

$$
X_{i}^{1}(k)=\left[x_{1}(k)-\min _{k} x_{1}(k)\right] /\left[\max _{k} x_{1}(k)-\min _{k} x_{1}(k)\right]
$$

\section{3) Calculating grey correlation coefficient}

Before calculating the contestant data sequence of grey correlation degree and standard data sequence, we have to calculate the contestant data and standard data sequences corresponding to each index data of grey correlation degree, namely the grey correlation coefficient. Grey correlation coefficient $X_{0 j}(k)$ of an indicator $x_{0}(k)$ used to define a standard data sequence data and of eligible data sequence index data is:

$$
Y_{0, j}(k)=\frac{\left\{\min _{i} \min _{k} \mid x_{0}(k)-x_{i}^{1}\left(k\left|+\zeta^{v} \times \max _{i} \max _{k}\right| x_{0}(k)-x_{i}(k) \mid\right\}\right.}{\left|x_{0}(k)-x_{i}(k)\right|+\zeta \times \max _{i} \max _{k}\left|x_{0}(k)-x_{i}(k)\right|}
$$

\section{Accounting informatization implementation strategy}

Strengthen the enterprise basic management and promote scientific management

Informatization is to take advantage of modern information technology, introduce of modern management idea, to conduct a comprehensive and profound changes to production mode, the mode of operation, the structure of the organization that not meet the needs of the enterprise. Information construction should be combined with the introduction of advanced management concept, in the introduction and use of advanced management software, we should pay attention to digest and absorb advanced management thoughts and ideas from the reality of the enterprise to change the traditional management idea and not let the mountain behind the advanced management software management style. 


\section{Strengthen the research of accounting informatization theory}

Accounting informatization cannot develop without the accounting informatization theory research. [5]Information is one of an important feature of the era of change, in order to meet the needs of the development of era, it is necessary to strengthen the research of accounting informatization theory, set up comparatively complete theory of accounting information system to guide practice better to adapt to the Times changes of accounting information requirements. From a certain sense, the process of production and the development of accounting informatization is the process that breaks through the traditional accounting concept.

\section{Speed up the cultivation of informatization talents}

Accounting informatization development is inseparable from the support of the people. At present, one outstanding problem existing in the development of accounting informatization is the lack of talent, especially the lack of high-quality talent, which greatly restricts the development of accounting informatization and propulsion. Although our country has adopted many policies and measures to strengthen the cultivation of accounting informatization talented person and have also had a batch of qualified personnel, but there is still a big gap between the actual needs.

\section{Summary}

The implementation of the enterprise accounting information can largely improve the enterprise management mode, utilize enterprise resources reasonably and improve the economic benefits of enterprises. However, enterprise of different size and different development degree is not the same on the implementation of accounting informatization degree. In choosing accounting informatization path, enterprise should choose accounting information software, decisions, and formulate the corresponding development strategy based on the development of their own condition.

\section{References}

[1] YVONNE M. VAN EVERDINGEN, A Mufti-Country Study of the Adoption of ERP Systems, Social Science Research Network, 2005.(9):16-18

[2] JosePhF. BrazelandLiDang, The Effect of ERP System in Presentations on the Usefulness of Accounting Information, Social Seines Research Network, 2005.(9):32-33

[3] TIRTHANKARROY, Business Process Reengineering-An Effective Management Tool, Social Science Research Network, 2005.(9):15-16

[4] Serafeimidis V,Smithson S.Information systems evaluation as an organizational institution-experience from a case study, Information Systems Journal, v.13,2005.

[5] Ying-Chyi Chou, Ying-Ying Hsu, Hsin-Yi Yen. Human resources for science and technology: Analyzing competitiveness using the analytic hierarchy process. Technology in Society, 2008, 30(2): $141-153$ 